The Presidenst, in supplement to his communication on melancholia, showed the mode of feeding which he adopted, which was discussed at some length by the members.

The meeting then terminated.

The members afterwards dined at Jury's Hotel, College Green. There were present Dr. Yellowlees, President of the Association, Dr. Finny, President of the Royal College of Physicians, Ireland, Dr. Bennett, Professor of Surgery, University of Dublin, Dr. Alec Fraser, Professor of Anatomy, R.C.S.I., Dr. Stewart Woodhouse, Medical Commissioner of the Prisons Board, Dr. Law Wade, Dr. J. W. Moore, Dr. G. P. L. Nugent, Dr. Kough, Dr. Aslec, Dr. Finnigan, Dr. Cope, Dr. Molony, Dr. Nash, and Dr. Norman.

\title{
Correspondence.
}

\section{A VISIT TO THE INSANE DEPARTMENT OF THE CHARITE HOSPITAL, BERLIN, AND THE ALLIED ASYLUM AT DALLDORF.}

\section{To the Editors of "The Journal of Mental Science."}

SIRs,-With your permission I propose to give here information and impressions concerning these institutions. In regard, firstly, to the psyohiatrioal clinic of the Charite - the well-known hospital situated in the north-western quarter of Berlin. It consists of three divisions-one for insane patients, a second for those liable to convulsive seizares, and a third for delirions patients. Professor Jolly is the Director, and subordinate to him are specialist physicians, who are Privat-Docenten, and are assisted by military assistant-physicians. The department is ntilized for teaching purposes ; in particular, cortain young students, or medical men, act in a capacity somewhat similar to that of clinioal clerk in our asylams. On the occasion of my visit, one of these took down the condition of patients from the physician's dictation. In cases of necessity, consultation is held with those in charge of other departments of the hospital. There is no regalar out-patient system ; occasionally, however, an examination is made of the mental condition of some criminal or other perscn (not an inmate) whose behaviour appears to demand it. The building iteelf (I now refer to the alienist department) is old, and but indifferently planned. Artistically viewed, the wards are unattractive. There is a deficiency of light and space; the corridurs are gloomy, the day-rooms and dormitories oramped, the latter being crowded with beds in a manner highly undesirable, but, it appears, unavoidable. The resources of the department are clearly taxed to a high degree. Dr. Boedeker, who kindly conducted me, informed me that, whilst there was sleeping accommodation for about 200, from 1,000 to 1,500 (and even more) patients pass throngh yearly. The Charité is, in fact, an institntion for acute and presumably-curable cases; patients regarded as incurable are transferred to Dalldorf. The average length of stay is, in the insane department, 22 days; in the department for epilepsy (including convulgive affections generally), 22 days for men, 34 for women. As regards the age of patients, most are between 20 and 50, as might be expected. The class re. sembles that seen at Betblem (recent and acute). Between the Charité and Bethlem there is much in common. Since the patients are drawn from Berlin and its environs much diversity of occupation is met with. Amongst the inmates are mechanics, tradesmen, merchants, artists, teachers, officials, and farmers. All the patients seen wore a uniform dress-jacket and trunsers, made of a light fabric like the night.costume of some people. In regard to 
treatment, the measures adopted do not differ much from those in rogue in Enulish asylums; noue of a specially energetic kind are used. The forms of exercise, too, are the ordinary. As much walking in familiar courts is done as in other asylums. Sedatives are but moderately used in the Charité. Mechanioal restraint is resorted to exceptionally, in comparison with past times. The number of attendants to patients I unfortunately forgot to inquire about. Padded and plain single rooms are made use of a good deal. Treatment by dotache and other forms of bath is adopted in cases similar to those so treated in this country. No uncommon methods are employed in the treatment of masturbation. Hypnotism has been and is still occasionally tried. If one may judge from the dearth of reports upon the subject one would suppose that success has been very limited. but some good results are said to have been achiered. The food provided looked good. The daily cost per head in the Charité is put down at three marks.

Cases of interest in the psychiatrical clinic are reported in the "CharitéAnnalen," in which records the surgical, medical, and other departments of the hospital are also represented. The following figures are derived from the "Annalen," xv., 1890. At the beginning of the year of report the department for the insane contained 127 patients ; the admissions in the year amounted to 1,318 , the discharges to 1,305 . Of these 252 were cured or improved, $911 \mathrm{nn}$ improved, 68 transferred to other departments or asylums, 74 were deaths.

The department for patients with convulsive seizares and that for delirions cases received together 1,192 in the year, and discharged 1,185, of whom 666 were cured or improved.

Dalldorf Asylum - situated at some little distance from Berlin, and reached by tram - has the appearance of the average English connty asylum. A long drive passes through the gronnds to the central blook; this is the administrative portion, but halls for theatricals and concerts are placed here also. Behind are the kitchens, laundry, and engine-houses. Stretching away on either side are five pavilions, male and female patients being accommodated on opposite sides, and separate pavilions devoted to epileptics, violent and excited (including some criminals found insane), and weak-minded patients. Criminals whose condition demands it are contined in a special parilion with special precantions. The building is modern, handsome, and of great size, and appears to be very well planned. The pavilions are well apart. The grounds are extensive. A director administers the entire institution, and has under his special charge the insane department proper; he is assisted by a physician (Oberarzt). A second director controls the department for infirm patients. In addition there are six assistant-physicians (one of whom, Dr. Otto, kindly conducted $\mathrm{me}$ ), and a dispenser. The number of patients in Dalldurf at the time of the last report was 1,349 ; the daily average 1,329 . The institution receives its patients in large measure from the Charité; they are mostly incurable. Nevertheless, many of the cases are highly interesting. The number of patients whose insanity is connected with gross lesions of the brain is exceptionally large; aphasia in different forms is met with frequently. In this connoction the pathological department may be mentioned. It is well equipped, and the papers published by the medical staff in the "Archiv f. Psychiatrie," "Zeitschr. f. Psych." and other Journals of the special kind, testify to the use made of the material at hand. Some paying patients are taken; the number may not exceed five per cent. of the total. They are only admitted when their ciroum. stances are insufficient to ineet the demands of a private asylum. They pay not less than one mark daily, and are treated just like the other patients. During the past year 72 were admitted.

The dornitories and wards - in connection with the latter are long corridors in which the patients promenade-are spacious, and well supplied with air and light. Mural decorations would not compare with those seen in many Finglish asylums, being extremely simple; but sanitary requirements are well attended 